\title{
Caries Management Strategies for Children with Autism Spectrum Disorder
}

\author{
Zaleha Shafiei ${ }^{1}$, Marisa Shanthini Thomas Shanta Kumar ${ }^{1}$, Anissha Engapuram ${ }^{1}$, \\ Ismail Nabil Albhaisi ${ }^{2}$, Ahmad Shuhud Zakaria ${ }^{3}$ and Shahida Mohd-Said ${ }^{2 *}$
}

\author{
${ }^{I}$ Department of Craniofacial Diagnostics and Biosciences, Faculty of Dentistry, Universiti Kebangsaan Malaysia. \\ Jalan Raja Muda Abdul Aziz, 50300 Kuala Lumpur, Malaysia \\ ${ }^{2}$ Department of Restorative Dentistry, Faculty of Dentistry, Universiti Kebangsaan Malaysia. Jalan Raja Muda Abdul \\ Aziz, 50300 Kuala Lumpur, Malaysia \\ ${ }^{3}$ Department of Family Oral Health, Faculty of Dentistry, Universiti Kebangsaan Malaysia. Jalan Raja Muda Abdul \\ Aziz, 50300 Kuala Lumpur, Malaysia \\ *Corresponding author. Email: shahidams@ukm.edu.my
}

\begin{abstract}
Due to their disability to communicate and impaired sensory and motor behaviours, children with autism spectrum disorder (ASD) present a challenge to the dental care providers hence resulting in difficult routine dental care as well as increased risk for dental caries and other dental infections. This review aims to acquire a deeper understanding of the best approach to manage carious lesions for children with ASD at home and in dental clinics. A literature search was carried out in Scopus, Web of Science, PubMed, and Cochrane databases using main keywords including 'carious lesion', 'paediatric', 'dental decay', and 'developmental disability. The inclusion criteria were full articles in the English language and studies related to dentistry only. Out of the initial 326 articles found from the search, 17 articles were eligible to be analysed at the end. Literature, as reported by the studies, was then qualitatively gathered and arranged thematically. Our review found several effective strategies for caries management of children with ASD including the use of behavioural modifications, visual pedagogy, use of pre-treatment audio-visual aids and applications. In addition, clinical preventive procedures using fluoride-based therapy and restorative treatments were also reported to be effective on these children than on comparative groups. The findings from this review could enlighten the health literacy and competency of caregivers when providing oral health care for children with ASD at home and in dental clinics and highlight the awareness on children's 'dental sensitivity' albeit the pain from dental caries.
\end{abstract}

Keywords: dental decay, developmental disability, dental management, children

\section{INTRODUCTION}

Autism spectrum disorder (ASD) is a life-long heterogeneous psychiatric disorder that is characterized by impairments in communication and social relationships and a restricted, repetitive and stereotyped repertoire of activities, behaviours and interests [1]. At the nosography classification level, in the Diagnostic and Statistical Manual of Mental Disorders, Fifth Edition (DSM V), ASD falls within the clinical category of neurodevelopmental disorders [2]. Given the complexities of ASD, a single trigger is improbable. 
The possible aetiologies of ASD are genetics, prenatal factors, brain biological factors and coexisting medical conditions [3].

Recent evidence shows that the prevalence of ASD in children is high and increasing [4]. About 1 in 54 or $1.85 \%$ of children have been identified with ASD according to estimates from CDC's Autism and Developmental Disabilities Monitoring (ADDM) Network in 2016 among 8-year-old children living in 11 communities in multiple areas of the United States [5]. It does not represent the entire population of children in the United States. Autism affects males four times more than females [6], and the cause for this difference is not well understood.

Dental caries is a chronic disease that commonly occurs during a lifetime. Dental caries occurs as a result of the demineralization of enamel and dentine by organic acids from the metabolism of dietary sugars by the bacteria in dental plaque. As a result, the lack of extensive training on proper tooth brushing by the parents and prolonged intake of sweet foods that are given as behavioural rewards or frequent snacking after meals increased the risk of developing dental caries among children with ASD [7]. Given the high prevalence of ASD, it is likely that an increasing number of dental practitioners will encounter or will be asked to treat children with ASD.

Dental visits behaviours also contribute to the treatment of dental caries and could prevent further destruction due to untreated dental caries. However, due to their disability to communicate and impaired sensory and motor behaviours, children with ASD present a challenge to the dentist with the skills or willingness to work with children with ASD. Hence, resulting in difficult routine dental care as well as increased risk for dental caries and other dental infections.

Since most oral related diseases can be prevented and children with ASD can be educated in specific ways, it is critical to building the true connection between oral health care and children with ASD in order to develop a preventive-therapeutic strategy to manage dental caries in these children [8]. Hence, the study is needed to know the best management strategies to handle and treat children with ASD from a carious lesion in the dental setting. This paper reviews explanations related to the treatment modalities for managing dental caries among children with ASD, the type of therapy, outcomes or benefits of the treatment, and how the caries-related symptoms and diagnosis affect dental treatment options and methods. Thus, this study was conducted with the aim to acquire a deeper understanding of the best approach to manage dental care for caries among children with ASD.

\section{MATERIALS AND METHODS}

\subsection{Search strategy}

Searches were conducted online using MEDLINE (via PubMed), Cochrane Library (via Wiley), the electronic repositories Web of Science and Scopus databases. The search was last performed in March 2021, using the following keywords: "caries management", "children", "dental caries" and "autism spectrum disorder". The keywords have been variably connected among them with the Boolean operators "AND" and "OR". Medical Subject Headings (MeSH) and previous related reviews and studies [9, 10] were also used to refine the search (Table 1).

\subsection{Eligibility criteria}

The inclusion criteria for this review were publications full articles in the English language and articles related to dentistry only while other fields of subjects were excluded. There was no year range for the articles searched. The articles obtained from each search in the above-mentioned databases were exported into Microsoft Excel. The list of articles was screened for duplicates, its irrelevance to the title of the study and non ASD related articles were rejected.

\subsection{Selection strategy}

The eligibility of all potential studies identified for inclusion was independently assessed by two reviewers. Some literature was excluded when the information was insufficient or when abstracts or full text articles were not able to be accessed. Where there was some doubt about the relevance of the articles, the disagreements that arise between the reviewers will be resolved through discussion with the supervising authors. The reviewers screened all the titles and abstracts and then an assessment of full texts was conducted. The reference lists of a relevant review article were also screened for other eligible papers. 
Table 1. Study search string

\begin{tabular}{|c|c|}
\hline Database & Search string \\
\hline Scopus & $\begin{array}{l}\text { [caries OR "caries therapy" OR "caries } \\
\text { control" OR "caries prevention") AND } \\
\text { (child* OR toddler OR teenager OR } \\
\text { adolescent) AND (“autism spectrum } \\
\text { disorder" OR ASD OR autism OR } \\
\text { "Asperger syndrome") AND (LIMIT-TO } \\
\text { (DOCTYPE, "ar")] AND [ LIMIT-TO } \\
\text { (SUBJAREA, "DENT") AND LIMIT-TO } \\
\text { (LANGUAGE, "English")] }\end{array}$ \\
\hline $\begin{array}{l}\text { Web of } \\
\text { Science }\end{array}$ & $\begin{array}{l}\text { [TS = (child* OR toddler OR teenager OR } \\
\text { adolescent) AND TS= ("autism spectrum } \\
\text { disorder" OR ASD OR autism OR } \\
\text { "Asperger syndrome") AND TS = (caries } \\
\text { OR "caries therapy" OR "caries control" } \\
\text { OR "caries prevention")] AND } \\
\text { LANGUAGE: (English) AND DOCUMENT } \\
\text { TYPES: (Article) } \\
\text { Refined by: WEB OF SCIENCE } \\
\text { CATEGORIES: (DENTISTRY ORAL } \\
\text { SURGERY MEDICINE) } \\
\text { Timespan: All years. Indexes: SCI- } \\
\text { EXPANDED, SSCI, A\&HCI, CPCI-S, } \\
\text { CPCI-SSH, BKCI-S, BKCI-SSH, ESCI. }\end{array}$ \\
\hline PubMed & $\begin{array}{l}\text { ("caries management" OR "dental caries } \\
\text { resistance" OR "caries resistance" OR } \\
\text { "Dental caries therapy" OR "caries } \\
\text { control" OR "caries prevention") AND } \\
\text { (child* OR minor OR toddler OR teenager } \\
\text { OR youth OR "young adult" OR } \\
\text { adolescent) AND (“autism spectrum } \\
\text { disorder" OR "Child development } \\
\text { disorders" OR "cognitive and } \\
\text { neurobehavioral disorders" OR } \\
\text { "intellectual disability") }\end{array}$ \\
\hline Cochrane & $\begin{array}{l}\text { [caries OR "caries therapy" OR "caries } \\
\text { control" OR "caries prevention") AND } \\
\text { (child* OR toddler OR teenager OR } \\
\text { adolescent) AND ("autism spectrum } \\
\text { disorder" OR ASD OR autism OR } \\
\text { "Asperger syndrome") } \\
\text { AND (LIMIT-TO (SUBJAREA, } \\
\text { "DENT")] AND [LIMIT-TO (LANGUAGE, } \\
\text { "English")] }\end{array}$ \\
\hline
\end{tabular}

\subsection{Data extraction}

Data was collected from qualified articles and inserted into a database in Microsoft Excel. From each article, the following information was obtained such as general characteristics (e.g., first author's name), study design and participant (e.g., types of study, the sample size of test and control groups), intervention, type of oral management (e.g., diagnostic method, preventive measurements, and restorative treatments) and outcome measures (e.g., factors attributing to changes or changes before and after intervention). Each data was then extracted from each article but not all data was present in every article.

\section{RESULTS AND DISCUSSION}

\subsection{Articles characterization}

Electronic database searches retrieved 319 articles and 7 articles were extracted from references of a systematic literature review article giving a total of 326 articles. Initial screening rejected 75 (23.01\%) of duplicates' articles, and 69 (21.17\%) articles were also rejected as it was not relevant to this study after screening the title and summaries of the rest of 251 articles. Out of 182 articles, only $173(53.07 \%)$ full text articles were available. All 173 full text articles were read, and 156 articles were rejected due to several reasons (e.g., not caries management, oral health status comparison of healthy and ASD children, dentists' perception, parents' perception, not dental management, not ASD related). A total of 17 articles were then selected to be used in our study as shown in the flow diagram of the systematic searching process (Figure 1).

Seventeen studies were included in this review and the detailed characteristics of these studies are displayed in Table 2. Eleven of these studies were cross-sectional, a quarter was retrospective (4/17), one was a randomized clinical trial, and one was an interventional study. All of these studies were varied in terms of intervention approaches to managing dental caries. The intervention used in each study was the management technique used for the participants, mainly children with ASD. Table 2 also lists the dental procedures that were reported to affect the treatments carried out in each sample, as well as the management strategies that were used during the procedures. All participants were used as the control group in almost half of the studies (7/17). Table 3 on the other hand shows clinical findings before and after the intervention were carried out for articles that made a comparison. The factors affecting the outcome of the findings were also mentioned where relevant. Out of 17 studies, a quarter of the studies (4/17) had substantial reductions in plaque index, and two of the studies had results related to the DMFT scoring, which is the best method of measurement to assess the intervention's effectiveness.

In this study, current evidence of treatment modalities for managing dental caries among children with ASD was reviewed. Several types of treatment modalities which include behavioural modifications techniques, visual pedagogies, intervention videos, apps development that related to the management of dental caries, preventative treatments (e.g., tooth brushing technique and fluoride therapy), and restorative treatments were reported by 17 articles that studied the management strategies of dental caries among children with ASD. Based on these 17 articles, this study would 


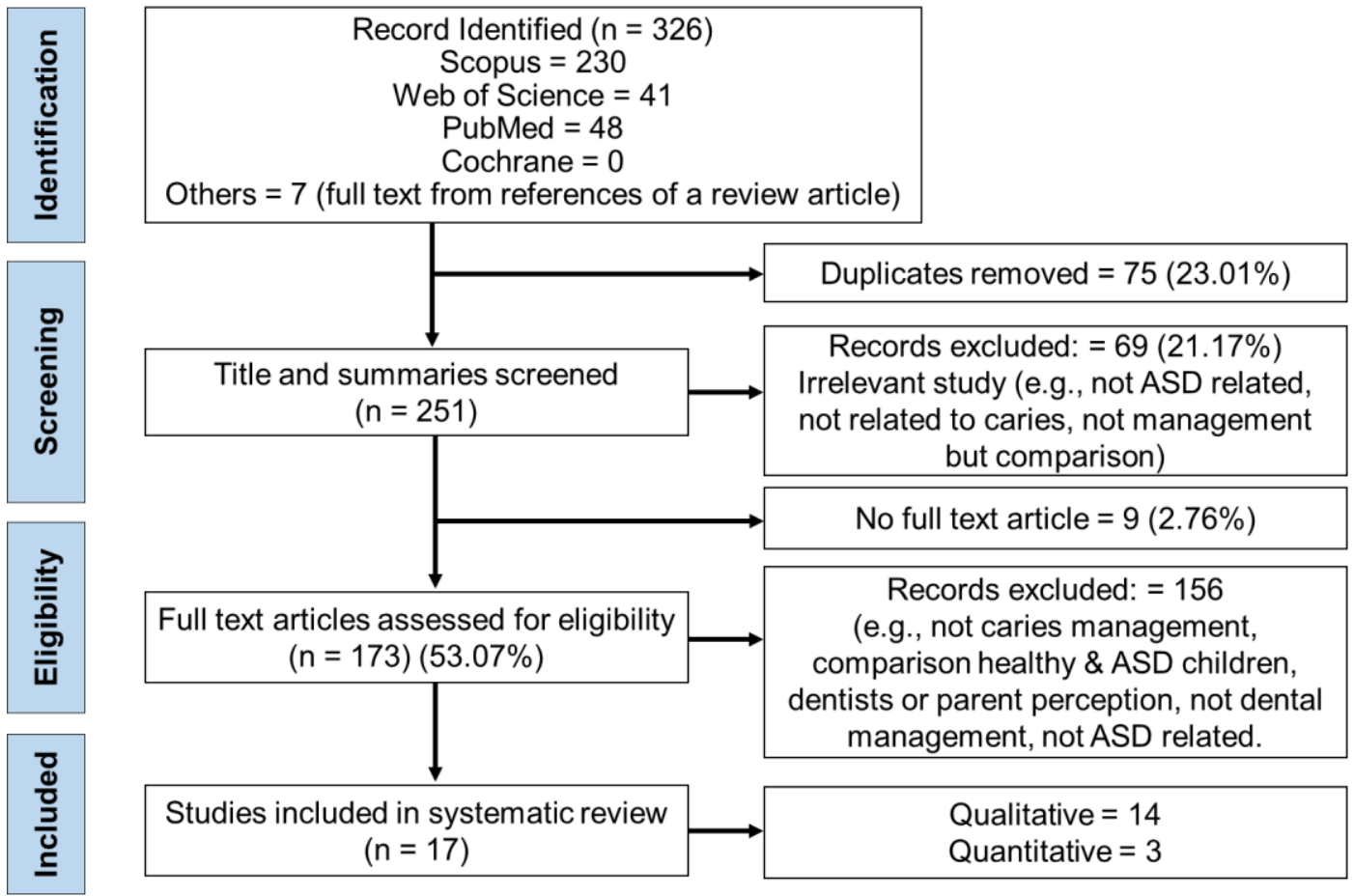

Figure 1 Flow chart of study selection process

\subsection{Effects of behavioural modification techniques on dental treatment}

Behavioural intervention as shown in Table 2 should be used as the first strategy to treat children with ASDs in the dental setting. Sensory adapted environment (SAE) is a type of behavioural management technique where the children are allowed to be accustomed to the sensory adaptations to clinical environments. The SAE has a strong soothing impact on both children with learning disabilities and normal children undertaking a high-anxiety treatment. Although all children were slightly more relaxed during dental treatment in SAE, the findings of this study suggest that children with developmental disabilities relaxed more than healthy children. SAE causes the participants' attention to be drawn to the moving visual and auditory stimuli thus distracting them from the discomfort or pain induced by the procedure which is scaling and prophylaxis [11].

Behavioural modification is also associated with good oral hygiene status. Implementation of Oral Health Education (OHE), especially the tooth brushing technique should be included in the curriculum for teachers as part of their training program. As a schoolbased early intervention program, it is believed to help children with ASD to improve their brushing technique which eventually improves their oral health [12]. This is supported by another study which indicated that the implementation of $\mathrm{OHE}$ and correct tooth brushing technique altered oral hygiene and plaque index among children with ASD. They also reported that caries prevalence decreases in those who brushed their teeth more than once daily [13].

The D-TERMINED Program was done by familiarization and repetitive tasking based on applied behaviour analysis theory. There are three repetition factors that lead to the success in the behaviour guidance technique among children with ASD include eye contact, positional modelling and counting framework during a dental procedure. This technique has shown significant improvement in the behaviour for the group that was practiced with the D-TERMINED program. When compared with the control group that used standard behavioural guidance techniques (SBGTs), the D-TERMINED group had significantly signed a lower percentage of referrals for dental treatment under general anaesthesia and the SGBT group, there was no discernible improvement in attitudes [14]. This study agreed with the finding from some previous studies that the SGBTs, including tellshow-do (TSD), voice control (VC), nitrous oxide (NO), passive restraint, and active restraint (AR), were not effective for children with ASD due to less cooperative during dental treatment and required general anaesthesia when compared to healthy group $[15,16]$.

A full mouth rehabilitation (FMR) program that was conducted in a group of physically disabled children to compare their oral health status with the control group, 
has been shown that the test group had improvement in oral symptoms and functional ability, as well as the mental and social wellbeing of ASD children at 6 months visit [17]. on toothbrushing techniques indicated a significant reduction of plaque index after 8 months [19]. However, Nilchian et al. reported that the use of visual pedagogy with a set of colouring pictures that illustrate the stepby-step stages of a dental visit for oral examination and

Table 2. Effects of behavior modification techniques on dental treatment among children with ASD

\begin{tabular}{|c|c|c|c|c|}
\hline Reference & Study design & Intervention & Dental procedure & Outcome \\
\hline $\begin{array}{l}\text { Shapiro et } \\
\text { al. [11] }\end{array}$ & $\begin{array}{l}\text { A cross-sectional } \\
\text { study } \\
\text { Test }=16 \\
\text { Control = } 19\end{array}$ & $\begin{array}{l}\text { Sensory adapted } \\
\text { environment }\end{array}$ & $\begin{array}{l}\text { - Dental prophylactic } \\
\text { - Calculus removal. } \\
\text { - Tooth cleaning with a } \\
\text { low-speed dental } \\
\text { handpiece and a rotary } \\
\text { bristle brush. }\end{array}$ & $\begin{array}{l}\text { - More relax than the } \\
\text { healthy children. } \\
\text { - Attention on moving } \\
\text { visual and auditory } \\
\text { stimuli distract from the } \\
\text { discomfort or pain. }\end{array}$ \\
\hline $\begin{array}{l}\text { Tong et al. } \\
{[12]}\end{array}$ & $\begin{array}{l}\text { A retrospective } \\
\text { study. } \\
158 \text { teachers from } \\
\text { five SPED schools } \\
\text { for children with } \\
\text { ASD Singapore. }\end{array}$ & $\begin{array}{l}\text { Implementation of } \\
\text { oral health education } \\
\text { (OHE) into teaching } \\
\text { curriculum (short } \\
\text { video on } \\
\text { toothbrushing } \\
\text { technique). }\end{array}$ & $\begin{array}{l}\text { - A presentation on } \\
\text { dental problems, OHE, } \\
\text { the role of teachers on } \\
\text { oral hygiene and } \\
\text { prevention of dental } \\
\text { diseases. } \\
\text { - Oral sensitivity. }\end{array}$ & $\begin{array}{l}\text { - Improve toothbrushing } \\
\text { technique. }\end{array}$ \\
\hline $\begin{array}{l}\text { Gadiyar et } \\
\text { al. [13] }\end{array}$ & $\begin{array}{l}\text { A cross-sectional } \\
\text { study. } \\
\text { Special } \\
\text { school children } \\
(n=223)\end{array}$ & $\begin{array}{l}\text { Toothbrushing } \\
\text { technique and } \mathrm{OHE}\end{array}$ & $\begin{array}{l}\text { - Type III clinical } \\
\text { examination. } \\
\text { - DMFT index. }\end{array}$ & $\begin{array}{l}\text { Decrease oral hygiene } \\
\text { and plaque index. }\end{array}$ \\
\hline $\begin{array}{l}\text { AlHumaid et } \\
\text { al. [14] }\end{array}$ & $\begin{array}{l}\text { A cross-sectional } \\
\text { study. } \\
\text { The D-TERMINED } \\
\text { program }(n=22) \text {. } \\
\text { SBGTs (control), } \\
(n=22)\end{array}$ & $\begin{array}{l}\text { D-TERMINED } \\
\text { Program of } \\
\text { Familiarization and } \\
\text { Repetitive }\end{array}$ & $\begin{array}{l}\text { - } 70 \% \text { received dental } \\
\text { treatment [cleanings, } \\
(50 \%) \text {, restorative } \\
(18 \%) \text {, extractions } \\
(2 \%) \text { ]. } \\
\text { - } 30 \% \text { did not have any } \\
\text { treatment } \\
\text { (uncooperative, referral } \\
\text { for general anesthesia). }\end{array}$ & $\begin{array}{l}\text { - Improvement in the } \\
\text { behavior } \\
\text { - lower percentage of } \\
\text { referrals and undergo } \\
\text { general anesthesia in } \\
\text { D-TERMINED program } \\
\text { group compared to } \\
\text { SBGTs group. }\end{array}$ \\
\hline $\begin{array}{l}\text { Al-Nowaiser } \\
\text { et al. [17] }\end{array}$ & $\begin{array}{l}\text { A cross-sectional } \\
\text { study. } \\
\text { Test }(n=97) \\
\text { Control }(n=89)\end{array}$ & $\begin{array}{l}\text { Full mouth } \\
\text { rehabilitation } \\
\text { (at a baseline and } 3 \\
\text { months visits) }\end{array}$ & $\begin{array}{l}\text { All children received } \\
\text { - Dental kits (electric } \\
\text { toothbrush, toothpaste, } \\
\text { tongue cleaners, } \\
\text { mouthwash). } \\
\text { - Oral hygiene } \\
\text { instructions (OHI) } \\
\text { - Oral hygiene. }\end{array}$ & $\begin{array}{l}\text { - Improve oral } \\
\text { symptoms, physical, } \\
\text { mental, and social } \\
\text { wellbeing at } 6 \text { months' } \\
\text { visit. }\end{array}$ \\
\hline
\end{tabular}

\subsection{Effects of audio-visual aids plus behavioural modification intervention on dental treatment}

Based on the evidence reviewed, visual pedagogy is the most recommended tool to facilitate dental treatments in children with ASD. A study by Cagetti et al. using the visual multistage protocol to undergo oral examination and treatments showed that most participants, regardless of verbal fluency, intellectual level, age, or gender, demonstrated good obedience to dental treatments. Their findings indicated that a professional hygiene technique was performed in over $90 \%$ of the sample and a fissure sealant was applied in over $80 \%$ of the subjects. This study concluded that behavioural intervention should be used as the first approach to treat ASD [18]. On the other hand, a study reported that visual pedagogy with a series of pictures preventive practices was only efficient in the case of fluoride therapy in ASD children with repeating the pedagogical and dental visits [20]. Another study confirmed that a tooth-brushing program using the picture exchange communication system (PECS) inhome dental care helps in oral education with a significantly reduced plaque index and gingival index at baseline and re-evaluation visits [21] (Table 3).

Video modelling on tooth brushing paired with email reminders intervention also can be a powerful means of providing information and resources to members of the autism community. Intervention video on toothbrushing technique alters oral health and plaque index as reported by Popple et al. [22]. Audio-visual distraction with video eyewear during dental procedure helps in behaviour modification among children with ASD regarding cooperation during dental examination 
and procedures such as dental $\mathrm{x}$ - rays, professional prophylaxis, and placement of sealant [23].

The cATED app is an App with pictures on a toothbrushing training program using an iPad®. This professional dental prophylaxis and reduced DMFT (decayed missed filled permanent tooth in permanent dentition) index among them. The presence of pictures and sound effects during the interaction with communication apps using $\mathrm{iPad} \circledast$ is more enjoyable and

Table 3. Effects of audio-visual aids on dental treatment among children with ASD

\begin{tabular}{|c|c|c|c|c|}
\hline References & Study design & Intervention & Dental procedure & Outcome \\
\hline $\begin{array}{l}\text { Cagetti et al. } \\
\text { [18] }\end{array}$ & $\begin{array}{l}\text { An interventional study. } \\
83 \text { disability children (6-12- } \\
\text { years old) } \\
\text { ( } 3 \text { groups based on age). }\end{array}$ & $\begin{array}{l}\text { Visual multistage } \\
\text { protocol (+ behavior } \\
\text { modification). }\end{array}$ & $\begin{array}{l}\text { - Oral examination } \\
\text { - Professional oral } \\
\text { hygiene session. } \\
\text { - Fissure sealant. } \\
\text { - Restorative treatment. }\end{array}$ & $\begin{array}{l}\text { - Good obedience } \\
\text { to dental } \\
\text { treatments. }\end{array}$ \\
\hline $\begin{array}{l}\text { Pilebro \& } \\
\text { Bäckman } \\
\text { [19] } \\
\text { Nilchian et } \\
\text { al. [20] }\end{array}$ & $\begin{array}{l}\text { A cross-sectional study. } \\
15 \text { children with autism and } \\
\text { their parents }\end{array}$ & $\begin{array}{l}\text { Color picture step- } \\
\text { by-step stages of a } \\
\text { dental visit and } \\
\text { toothbrushing }\end{array}$ & $\begin{array}{l}\text { - Dental examination } \\
\text { - Bitewing radiograph } \\
\text { - Plaque index } \\
\text { - Plaque score, } \\
\text { - Gingival score } \\
\text { - DMFT score before, } \\
\text { after } 8 \text { and } 12 \text { months. }\end{array}$ & $\begin{array}{l}\text { - Plaque index } \\
\text { reduced after } 8 \\
\text { months. }\end{array}$ \\
\hline $\begin{array}{l}\text { Al-Batayneh } \\
\text { et al. [21] }\end{array}$ & $\begin{array}{l}\text { A retrospective study. } \\
\text { Test }(n=20) \text {. } \\
\text { Control }(n=20) \text {. }\end{array}$ & $\begin{array}{l}\text { Picture exchange } \\
\text { communication } \\
\text { system (PECS) on } \\
\text { toothbrushing } \\
\text { program }\end{array}$ & $\begin{array}{l}\text { - Oral examination. } \\
\text { - Oral hygiene. } \\
\text { - Gingival health. } \\
\text { - DMFT scores. }\end{array}$ & $\begin{array}{l}\text { Efficient in the } \\
\text { case of fluoride } \\
\text { therapy with } \\
\text { repeating the } \\
\text { pedagogical and } \\
\text { dental visits. }\end{array}$ \\
\hline $\begin{array}{l}\text { Popple et al. } \\
\text { [22] }\end{array}$ & $\begin{array}{l}\text { A cross-sectional study. } \\
\text { Test }(n=9) \text { watched the } \\
\text { intervention video modeled } \\
\text { proper brushing technique. } \\
\text { Control: }(n=9) \text { watched the } \\
\text { control video (moving, } \\
\text { colorful fractal images + } \\
\text { music). }\end{array}$ & $\begin{array}{l}\text { Video modelling } \\
\text { toothbrushing } \\
\text { intervention }\end{array}$ & $\begin{array}{l}\text { - Oral health. } \\
\text { - Plaque index. }\end{array}$ & $\begin{array}{l}\text { - Alter oral health } \\
\text { and plaque index. }\end{array}$ \\
\hline $\begin{array}{l}\text { Fakruddin et } \\
\text { al. [23] }\end{array}$ & $\begin{array}{l}\text { A retrospective study. } \\
28 \text { ASD children ( } 17 \text { boys } \\
\text { and } 11 \text { girls) }\end{array}$ & $\begin{array}{l}\text { Audiovisual } \\
\text { distraction with } \\
\text { video eyewear }\end{array}$ & $\begin{array}{l}\text { - Oral examination. } \\
\text { - Dental procedure (x- } \\
\text { rays, professional } \\
\text { prophylaxis, sealant). }\end{array}$ & $\begin{array}{l}\text { Help in behavior } \\
\text { modification with } \\
\text { high cooperation. }\end{array}$ \\
\hline $\begin{array}{l}\text { Cazaux et } \\
\text { al. [24] }\end{array}$ & $\begin{array}{l}\text { A cross-sectional study. } \\
52 \text { ASD children }\end{array}$ & $\begin{array}{l}\text { cATED App } \\
\text { (Toothbrushing } \\
\text { training program } \\
\text { using an iPad) }\end{array}$ & $\begin{array}{l}\text { - Visual activity of } \\
\text { toothbrushing on an } \\
\text { iPad using an çATED } \\
\text { App (> } 8 \text { months). }\end{array}$ & $\begin{array}{l}\text { Desensitize and } \\
\text { enhance brushing } \\
\text { habit. }\end{array}$ \\
\hline $\begin{array}{l}\text { Zink et al. } \\
\text { [25] }\end{array}$ & $\begin{array}{l}\text { A cross-sectional study } \\
\text { Test }(n=20) \text { :app evaluation. } \\
\text { Control }(n=20) \text { : PECS } \\
\text { evaluation. }\end{array}$ & $\begin{array}{l}\text { Communication app } \\
\text { using iPad with } \\
\text { audio describing the } \\
\text { stages of dental } \\
\text { treatment and } \\
\text { compare with PECS }\end{array}$ & $\begin{array}{l}\text { - Professional } \\
\text { prophylaxis } \\
\text { - Topical fluoride } \\
\text { application } \\
\text { (Unflavored } 2 \% \text { sodium } \\
\text { fluoride gel). } \\
\text { - DMFT index. }\end{array}$ & $\begin{array}{l}\text { - Reduce DMFT } \\
\text { index. } \\
\text { - Increase } \\
\text { willingness for } \\
\text { dental. } \\
\text { appointments. } \\
\text { - Attractive to } \\
\text { explore the } \\
\text { picture on iPad } \\
\text { Mini compared to } \\
\text { PECS. }\end{array}$ \\
\hline
\end{tabular}

app is simple, innovative, encourages motivation for learning and eases the difficulties with social communication among children with ASD. This training program can desensitize them and enhance their brushing habit [24]. The development of a communication App using the iPad which describes the phases of dental treatment during the first visit also encourages the children with ASD to receive effective when compared to the picture exchange communication system (PECS). This enhances willingly attended the dental appointments among these children and quickly sought out the iPad Mini to explore the pictures. While the motivation for exploring pictures on flashcards (or PECS) seemed to be less, and, under any circumstances, the patient was distracted by other 
attractive objects present in the dental office, such as a toy [25] (Table 3).

\subsection{Effects of dental treatment procedures}

Table 4. Effects of dental treatment procedures among children with ASD

\begin{tabular}{|c|c|c|c|c|}
\hline References & Study design & Intervention & Dental procedure & Outcome \\
\hline $\begin{array}{l}\text { Baygin et al. } \\
\text { [26] }\end{array}$ & $\begin{array}{l}\text { A controlled clinical trial } \\
\text { study. } \\
\text { Test } 1(n=30) \text { : Fluoride } \\
\text { varnish. } \\
\text { Test } 2(n=30) \text { : Combination } \\
\text { of CHX. } \\
\text { Control }(n=30) \text { : Fluoridated } \\
\text { toothpaste } \\
\text { (12 months). }\end{array}$ & $\begin{array}{l}\text { Fluoride varnish, and } \\
\text { a combination of } \\
\text { chlorhexidine-thymol } \\
\text { varnish and } \\
\text { chlorhexidine-fluoride } \\
\text { gel. }\end{array}$ & $\begin{array}{l}\text { - Oral hygiene } \\
\text { procedure. }\end{array}$ & $\begin{array}{l}\text { Lower PI, GI, } \\
\text { Mutans } \\
\text { Streptococci and } \\
\text { Lactobacilli scores } \\
\text { at } 1 \text { and } 6 \text { months. }\end{array}$ \\
\hline $\begin{array}{l}\text { Wajawat et al. } \\
\text { [27] }\end{array}$ & $\begin{array}{l}\text { A cross-sectional study. } \\
\text { Test }(n=20) \text { : powered } \\
\text { toothbrush. } \\
\text { Control }(n=20) \text { : manual } \\
\text { toothbrush. }\end{array}$ & $\begin{array}{l}\text { Efficacy of powered } \\
\text { and manual } \\
\text { toothbrushes } \\
\text { (+demo: } \\
\text { toothbrushing using } \\
\text { tooth model) }\end{array}$ & $\begin{array}{l}\text { - Individual } \\
\text { tailor-made OHIs. } \\
\text { - PI and GI index at } \\
\text { baseline, } 1,4 \text {, and } \\
12 \text { weeks. }\end{array}$ & $\begin{array}{l}\text { - Improve } \\
\text { toothbrushing } \\
\text { technique using } \\
\text { powered } \\
\text { toothbrushes. }\end{array}$ \\
\hline $\begin{array}{l}\text { Awasthi et al. } \\
\text { [28] }\end{array}$ & $\begin{array}{l}\text { A cross-sectional study. } \\
\text { Test }(n=11) \text { : powered } \\
\text { toothbrush. } \\
\text { Control }(n=11) \text { : manual } \\
\text { toothbrush }\end{array}$ & $\begin{array}{l}\text { Low fluoridated and } \\
\text { calcium-based } \\
\text { dentifrices with } \\
\text { powered and manual } \\
\text { toothbrushes } \\
\text { (+demo: audiovisual } \\
\text { aid on toothbrushing } \\
\text { technique). }\end{array}$ & $\begin{array}{l}\text { - Simplified oral } \\
\text { hygiene index (OHI- } \\
\text { S). } \\
\text { - DMFT, GI and PI } \\
\text { - Oral hygiene. } \\
\text { - Demonstration of } \\
\text { brushing technique } \\
\text { to children, parents, } \\
\text { and teachers } \\
\end{array}$ & $\begin{array}{l}\text { A powered } \\
\text { toothbrush with } \\
\text { calcium sucrose } \\
\text { phosphate-based } \\
\text { formulation-Enafix } \\
\text { decreased PI and } \\
\text { Gl. }\end{array}$ \\
\hline $\begin{array}{l}\text { Robertson et } \\
\text { al. [29] }\end{array}$ & $\begin{array}{l}\text { A retrospective study. } \\
16 \text { children with learning } \\
\text { disabilities had } 27 \text { crowns } \\
\text { placed using the HT. }\end{array}$ & Hall technique (HT) & $\begin{array}{l}\text { - The clinical } \\
\text { assessment } \\
\text { - radiographic } \\
\text { evaluation of teeth } \\
\text { treated with the HT. }\end{array}$ & $\begin{array}{l}\text { - no further pain or } \\
\text { infection. } \\
\text { - no mechanical loss } \\
\text { of crown. } \\
\text { - no secondary } \\
\text { caries. } \\
\text { - stop general } \\
\text { anesthesia. }\end{array}$ \\
\hline
\end{tabular}

Several studies found that the quality of oral hygiene improved with the usage of toothbrushes and fluoridated toothpaste. Fluoride gel and Chlorhexidine, an antibacterial agent, were successful in eliminating cariogenic factors and improving oral hygiene when used in combination with tooth brushing. This is compatible with the study findings by Baygin et al. which showed that groups 1 and 2 who use respective fluoride varnish, and a combination of chlorhexidinethymol varnish plus a gel containing chlorhexidine and fluoride, had significantly lower plaque index (PI), gingival index (GI), Mutans Streptococci and Lactobacilli scores at 1 and 6 months than group 3, which did not use any of the interventions [26]. The overall dental health status of children with ASD benefited from the usage of powered toothbrushes besides improving their motivation and compliance, and when compared to the control group (who use manual toothbrushing), the PI and gingival health were much improved [27]. A similar result revealed that using a powered toothbrush with calcium sucrose phosphate- based formulation - Enafix decreased the mean value of PI and GI significantly [28] (Table 4).

Hall technique (HT) is a conventional technique used for caries management either in children with ASD or healthy children. The crown when placed in this technique sealed the carious lesion thus halting the progression of caries thus there was no further pain or infection reported during the follow-up. There is no mechanical loss of crown, and no secondary caries were reported using the HT. The HT was found to be an appropriate and successful option for treating carious primary molars in children with learning disabilities, according to the findings of this prospective cohort study. This alternate treatment plan could help children stop having to go under general anaesthesia [29] (Table 4).

Finding from these reviews is to educate dentists on the multiple techniques or strategies that they can use to manage children with ASD in their dental practice. This is so that patients with ASD will feel more comfortable attending dental appointments as their dentists are well versed in managing patients with ASD. This study has some limitations. Most studies have a limited sample size, so a larger sample size is needed to demonstrate the best impact of certain methods on caries 
management. Some of the studies lack a comparative group to demonstrate the efficacy of specific methods. It is also recommended for future researchers to further investigate the safest preventive approach to the management of dental caries among children with ASD.

\section{CONCLUSION}

Our finding found substantial evidence on the use of behavioural modification techniques, audio-visual aids as well as preventive and restorative treatment procedures to effectively manage caries among children with ASD in dental clinics. The findings from this study may provide more insight to dental professionals on alternative strategic treatment management for children with ASD in dental clinics.

\section{AUTHORS' CONTRIBUTIONS}

Z.S and S.M.S: Design, content, data analysis, initial draft, final review; M.S.T., A.E and I.N.B.: content, data collection, data analysis, initial draft; A.S.I.Z.: Final review, funding.

\section{ACKNOWLEDGMENTS}

The authors would like to thank the Dean of Faculty of Dentistry of Universiti Kebangsaan Malaysia for their support in completing this study. We would also like to take this opportunity to thank Translational Research (TR@M): Program Penyelidikan Strategik Kementerian Pendidikan Malaysia (TRANSLATIONAL-2019-001/2) for funding this study. The funders had no role in study design, data collection and analysis, decision to publish, or preparation of the manuscript.

\section{REFERENCES}

[1] H. Faras, N. Al Ateeqi, L. Tidmarsh, Autism spectrum disorders, Annals of Saudi Medicine 30(4) (2010) 295-300. DOI: 10.4103/02564947.65261

[2] American Psychiatric Association, Diagnostic and statistical manual of mental disorders, Fifth Edition, DSM-5 Update (2018) 1-74.

[3] L. Dall'Aglio, T. Muka, C.A.M. Cecil, W.M. Bramer, The role of epigenetic modifications in neurodevelopmental disorders: A systematic review, Neuroscience \& Biobehavioral Reviews (2018) 1-44. DOI: https://www.researchgate.net/publication/3265406 21

[4] T.F. Boat, J.T. Wu, Mental disorders and disabilities among low-income children, National Academies Press (US), Washington (DC), (2015) 353-361. DOI: $10.17226 / 21780$
[5] M.J. Maenner, K.A. Shaw, J. Baio, et al. Prevalence of autism spectrum disorder among children aged 8 Years-Autism and developmental disabilities monitoring network, 11 Sites, United States, 2016. MMWR Surveillance Summaries 69(SS-4) (2020) 1-12. DOI: http://dx.doi.org/10.15585/mmwr.ss6904a1externa 1 icon

[6] E. Fombonne, Epidemiology of autistic disorder and other pervasive developmental disorders, Journal of Clinical Psychiatry 66(10) (2005) 3-8.

[7] N. Hariyani, R.H. Soebekti, D. Setyowati, T. Bramantoro, L.S. Palupi, Oktarina, E. Putriana, Factors influencing the severity of dental caries among Indonesian children with autism spectrum disorder - a pilot study. Clinical, Cosmetic and Investigational Dentistry 11 (2019) 227-233. DOI: 10.2147/CCIDE.S205041

[8] B. Reichow, A.M. Steiner, F. Volkmar, Cochrane review: social skills groups for people aged 6 to 21 with autism spectrum disorders (ASD), EvidenceBased Child Health 8(2) (2013) 266-315. DOI: 10.1002/ebch.1903

[9] G.F. Ferrazzano, C. Salerno, C. Bravaccio, A. Ingenito, G. Sangianantoni, T. Cantile, Autism spectrum disorders and oral health status: review of the literature, European Journal of Paediatric Dentistry 21(1) (2020) 9-12. DOI: 10.23804/ejpd.2020.21.01.02

[10] K. Delli, P.A. Reichart, M.M. Bornstein, C. Livas, Management of children with autism spectrum disorder in the dental setting: Concerns, behavioural approaches and recommendations, Medicina Oral, Patologia Oral y Cirugia Bucal 18(6) (2013) e862-e868. DOI 10.4317/medoral.19084

[11] M. Shapiro, H.D. Sgan-Cohen, S. Parush, R.N. Melmed, Influence of adapted environment on the anxiety of medically treated children with developmental disability, Journal of Pediatrics 154(4) (2009) 546-550. DOI 10.1016/j.jpeds.2008.10.017

[12] H.J. Tong, H.Y. Lee, Y.T. Lee, Y. Low, C.R. Lim, R. Nair, Factors influencing the inclusion of oral health education in individualized education plans of children with autism spectrum disorders in Singapore, International Journal of Paediatric Dentistry 27(4) (2017) 255-263. DOI 10.1111/ipd. 12257

[13] A. Gadiyar, R. Gaunkar, A.K. Kamat, A. Tiwari, A. Kumar, Impact of oral health-related behaviors on dental caries among children with special health-care needs in Goa: A cross-sectional study, Journal of Indian Society of Pedodontics and 
Preventive Dentistry 36(1) (2018) 33-37. DOI: 10.4103/JISPPD.JISPPD_214_17

[14] J. AlHumaid, D. Tesini, M. Finkelman, C.Y. Loo, Effectiveness of the D-TERMINED program of repetitive tasking for children with autism spectrum disorder, Journal of Dentistry for Children 83(1) (2016) 16-21.

[15] J. Marshall, B. Sheller, B.J. Williams, L. Mancl, C. Cowan, Cooperation predictors for dental patients with autism, Pediatric Dentistry 29(5) (2007) 369376.

[16] C.Y. Loo, R.M. Graham, C.V. Hughes, The caries experience and behavior of dental patients with autism spectrum disorder, Journal of the American Dental Association 139(11) (2008) 1518-1524. DOI: $10.14219 /$ jada.archive.2008.0078

[17] A.M. Al-Nowaiser, A.S. Al Suwyed, K.H. Al Zoman, et al., Influence of full mouth rehabilitation on oral health-related quality of life among disabled children, Clinical and Experimental Dental Research 3(5) (2017) 171178. DOI: $10.1002 / \mathrm{cre} 2.78$

[18] M.G. Cagetti, S. Mastroberardino, G. Campus, B. Olivari, R. Faggioli, C. Lenti, L. Strohmenger, Dental care protocol based on visual supports for children with autism spectrum disorders, Medicina Oral, Patologia Oral y Cirugia Bucal 20(5) (2015) e598-604. DOI: 10.4317/medoral.20424

[19] C. Pilebro, B. Bäckman, Teaching oral hygiene to children with autism, International Journal of Paediatric Dentistry 15 (2005) 1-9. DOI: 10.1111/j.1365-263X.2005.00589.x

[20] F. Nilchian, F. Shakibaei, Z.T. Jarah. Evaluation of visual pedagogy in dental check-ups and preventive practices among 6-12-year-old children with autism, Journal of Autism and Developmental Disorders 47(3) (2017) 858-864. DOI: 10.1007/s10803-016-2998-8

[21] O.B. Al-Batayneh, T.S. Nazer, Y.S. Khader, A.I. Owais, Effectiveness of a tooth-brushing programme using the picture exchange communication system (PECS) on gingival health of children with autism spectrum disorders, European Archives of Paediatric Dentistry 21(2) (2019) 277-283. DOI: 10.1007/s40368-019$00485-\mathrm{x}$

[22] B. Popple, C. Wall, L. Flink, et al., Brief report: remotely delivered video modeling for improving oral hygiene in children with ASD: a pilot study, Journal of Autism and Developmental Disorders 46(8) (2016) 2791-2796. DOI: 10.1007/s10803016-2795-4
[23] K.S. Fakhruddin, H.Y. El Batawi. Effectiveness of audiovisual distraction in behavior modification during dental caries assessment and sealant placement in children with autism spectrum disorder, Dental Research Journal 14(3) (2017) 177-182. DOI: 10.4103/1735-3327.208768

[24] S.L. Cazaux, G. Lefer, A. Rouches, P. Bourdon. Toothbrushing training programme using an $\mathrm{iPad}{ }^{\circledR}$ for children and adolescents with autism, European Archives of Paediatric Dentistry 20(3) (2019) 277 -284. DOI: 10.1007/s40368-018-0396-y

[25] A.G. Zink, E.C. Molina, M.B. Diniz, M.T.B.R. Santos, R.O. Guaré. Communication application for use during the first dental visit for children and adolescents with autism spectrum disorders, Pediatric Dentistry 40(1) (2018) 18-22.

[26] O. Baygin, T. Tuzuner, A. Kusgoz, A.C. Senel, M. Tanriver, I. Arslan. Antibacterial effects of fluoride varnish compared with chlorhexidine plus fluoride in disabled children, Oral Health and Preventive Dentistry 12(4) (2014) 373-382. DOI: 10.3290/j.ohpd.a32129

[27] M. Vajawat, P.C. Deepika, V. Kumar, P. Rajeshwari, A clinicomicrobiological study to evaluate the efficacy of manual and powered toothbrushes among autistic patients, Contemporary Clinical Dentistry 6(4) (2015) 500504. DOI: 10.4103/0976-237X.169848

[28] P. Awasthi, B. Peshwani, S. Tiwari, R. Thakur, N.D. Shashikiran, S. Singla, Evaluation and comparison of the efficacy of low fluoridated and calcium phosphate-based dentifrice formulations when used with powered and manual toothbrush in children with autism, Contemporary Clinical Dentistry 6(2) (2015) S188-S191. DOI:10.4103/0976-237X.166811

[29] M.D. Robertson, J.C. Harris, J.R. Radford, N.P.T. Innes, Clinical and patient-reported outcomes in children with learning disabilities treated using the Hall Technique: A cohort study, British Dental Journal 228(2) (2020) 93-97. DOI: 10.1038/s41415-019-1166-x 